\title{
Perception of Concept and Practice of Social Power in Development Interventions in Malawi \\ https://dx.doi.org/10.4314/jae.v23i3.13
}

\section{Chimgonda-Nkhoma, Jerome, J.}

Agriculture Extension Services, Ministry of Agriculture, Irrigation and Water Development, Lilongwe, Malawi

Email: jeronkhoma@yahoo.co.uk; Phone: +265996760503

\section{Garforth, Chris J.}

School of Agriculture, Policy and Development, University of Reading, England, United Kingdom.

Email: c.j.garforth@reading.ac.uk; Phone: +44 (0) 1183788314

\section{Cardey, Sarah. P.}

School of Agriculture, Policy and Development, University of Reading, England, United Kingdom.

Email: s.p.cardey@reading.ac.uk; Phone: +44 (0) 1183786594

\section{Aderinoye-Abdulwahab, Sidiqat. A.}

Department of Agricultural Extension \& Rural Development, University of llorin, llorin, Nigeria

Email: aderinoye.as@unilorin.edu.ng; Phone: +2348033594496

Fawole, Bolaji. E.

Department of Agricultural Extension \& Rural Development, Federal University Dutsin-Ma, Katsina State

Email: bfawole@fudutsinma.edu.ng; Phone: +2348039206467

\section{Abstract}

The study examined research participants' perception of social power in intervention programmes in Malawi. Two districts and four villages with active participation in the intervention programmes were purposively selected. Focus group participants were purposively identified, while the snow balling procedure was employed to select key informants. A total of 375 participants consisting of 219 men and 156 women (to better explore the viewpoints of men from those of women) were drawn from the two study locations. Data were analysed by content analysis. The results showed that $>98 \%$ of participants stated that power meant the 'capacity of a social actor to influence decisions and secure compliance of other social actors. Less than $98 \%$ also perceived 'power' as the leadership ability of a social actor but few participants with high level of power shared this construct. Further analysis informed that power was perceived as the act of guiding fellow social actors to plan and implement activities serving common interest while another $50 \%$ of respondents perceived power as a mere potential ability to influence. Statistics however showed only 3.7\% of relatively powerful social actors from agricultural extension workers and $1.3 \%$ of sexual and reproductive health interventionists shared power as potential ability to influence way 
Creative Commons User License: CC BY-NC-ND

Abstracted by: EBSCOhost, Electronic Journals Service (EJS),

Google Scholar, Journal Seek, Scientific Commons,

Food and Agricultural Organization (FAO), CABI and Scopus
Journal of Agricultural Extension

Vol. 23 (3) July, 2019

ISSN(e): 24086851; ISSN(Print); 1119944X

http://journal.aesonnigeria.org

http://www.ajol.info/index.php/iae

Email: editorinchief@aesonnigeria.org

of thinking and doing. Therefore, stakeholders of development intervention should recognize experienced social actors and traditions as power indicators since these will enhance effective extension policy process aimed at development intervention among rural populace.

Keywords: Participants, village level, intervention, influence, leadership

\section{Introduction}

Power is important in social, political, and economic development processes because of its positive and negative influence on the processes. Despite the importance of the concept, there is no standard meaning of power to guide its application in different social contexts. Review of literature of power shows that the concept has different meanings (Pereira et al., 2016). Multiple meanings challenge the use of a single definition of power in different social contexts (Pansardi, 2012). Although, social power is a sub-category of power, however, in this article the two terms are used synonymously for convenience. Whilst, studies of social power have shown contrasting views about the concept (Dowding, 2012). Debates concerning power and its dynamics in society have been raging for decades. The debates have aimed at understanding power and its relations in different social contexts. Again, different theories of power underpin the debates in social and development contexts. Hence, in this article, we try to contextualize power as perceived by actors from agriculture and health interventions in Malawi.

Theorists of power construe power as a social actor's ability to make decisions and achieve specific outcomes even in the wake of resistance. This relates to descriptions of pluralists who conceive social power in terms of outcomes. This shows that framers of the concept view it as an action that produces specific outcome(s) in a social context. The pluralist view of power suggests domination and coercion in society. Pluralists, therefore, consider power as an attribute of social actors and that it is exercised in their relationships.

The perceptions presented here suggest that power is a relational phenomenon where some actors possess it while other actors do not have power. However, some scholars challenge this view and argue that everyone has power in society. This is an ideological debate and needs to be ascertained from interactions with social actors in social contexts.

The goal of the agriculture and health interventions in villages include ensuring food security and reducing maternal, neonatal morbidity and mortality with a view to achieving improved maternal health and child mortality. The purpose of the reproductive health programme in Malawi was to promote safer health practices by men, women and young people, including increased use of high quality and accessible reproductive health services. The agricultural interventions aimed to diversify sources of food and improve the levels of household income through promotion of investments in diverse income-generating activities, value addition to agricultural produce through post-harvest storage and processing, and enhancing entrepreneurial skills and access to input and output markets. The interventions also aimed to protect and improve the agricultural potential of the land through conservation of natural resources. Specific activities ranged from provision of information for production of crops, vegetables, and animals. The villagers in the catchment areas played active roles in 
Creative Commons User License: CC BY-NC-ND

Abstracted by: EBSCOhost, Electronic Journals Service (EJS),

Google Scholar, Journal Seek, Scientific Commons,

Food and Agricultural Organization (FAO), CABI and Scopus
Journal of Agricultural Extension

Vol. 23 (3) July, 2019

ISSN(e): 24086851; ISSN(Print); 1119944X

http://journal.aesonnigeria.org

http://www.ajol.info/index.php/iae

Email: editorinchief@aesonnigeria.org

planning and implementation of the development interventions. Hence, power play out in the success of both interventions through the village leadership. The leadership comprises the village head, elders and advisors to the village head who form a de-facto council of ministers at that level. The village leadership ensures adherence to the customs by its citizens. It also guides its citizens in the planning and implementation of development interventions within the cultural setting.

Review of studies of power reveals gaps in the theories of social power. Although survey of the literature of social power shows many definitions of the concept; this does not suggest that all definitions are valid in all social contexts (Dowding, 2012). This is because power is a social construct that may be determined by clearly assigned and explicitly defined roles of a particular society (Pereira et al., 2016). This paper identifies three gaps in the study of social power. First is that there is no standard definition of the concept to guide understanding of the roles that power plays in different social contexts. Secondly, the prevalence of multiple meanings of social power results in ambiguities when using the concept unless it is clearly defined in a specific context and finally, the ambiguities may wrongly inform theory, decisions, actions, and policy that border on power issues such as empowerment in development interventions. The quest for bridging these gaps and addressing the problems in development theory and practice necessitated this study.

The study addressed the challenges by establishing perception(s) of power in a particular context especially of how development stakeholders define power as this may be important to development because it can inform development strategies that use power. Understanding the context is important to this study as it influences implementation of the interventions. Besides this, the structures represented a broad range of social actors in the Malawian rural development context. The actors were policy makers, political party leaders, traditional leaders, religious leaders, development workers, and ordinary citizens from villages. Thus, this study sought to understand the concept of power and its motivating factors in the development context. The context described represented the practical rural development perspective in the country of study. Examining the perceptions of power from the perspective of extension development workers in agriculture and health related interventions is important for improved clarity of theories, strategies, and practices relating to the concept in development.

\section{Methodology}

Malawi, the study country is located on latitude $13^{\circ} 30^{\prime} \mathrm{S}$ and longitude $34^{\circ} 00^{\prime} \mathrm{E}$. In Malawi, 'village' is a cluster of households in the same geographical area. The village is identified with a name, tribe, and corresponding customs including language. It is governed by a village head and auxiliary leaders, who use cultural norms and bylaws. The leadership comprises the village head, elders and advisors to the village head who form a de-facto council of ministers at that level. The village leadership ensures adherence to the customs by its citizens. It also guides its citizens in the planning and implementation of development interventions within the cultural setting. The village was chosen as a unit of study for two reasons. It is the basic structure for cultural activities in the traditional context and it is also the unit used for planning and implementation of development interventions. 
Creative Commons User License: CC BY-NC-ND

Abstracted by: EBSCOhost, Electronic Journals Service (EJS),

Google Scholar, Journal Seek, Scientific Commons,

Food and Agricultural Organization (FAO), CABI and Scopus
Journal of Agricultural Extension

Vol. 23 (3) July, 2019

ISSN(e): 24086851; ISSN(Print); 1119944X

http://journal.aesonnigeria.org

http://www.ajol.info/index.php/iae

Email: editorinchief@aesonnigeria.org

There are 28 districts in Malawi out which 2 districts were purposively selected based on sponsors concentration of development intervention that were purely food security. Four villages were purposively selected from each of the two districts based on concentration of both food security and sexual and reproductive health interventions.

A questionnaire with open-ended questions was designed in the vernacular language of Malawi-Chichewa' in order to triangulate results. Focus group discussions, key informant interviews, direct observations, document analysis, were used to collect data. Focus group discussion participants were purposively identified based on active participation in the intervention activities while the snow balling procedure was employed to select key informants. The participants were randomly selected from each of the villages to give a total of 375 participants (Table 1). The sample consists of 219 men and 156 women who were drawn from the two study locations. 189 men and 133 women participated in 30 focus group discussions, while 53 key informants ( 30 men and 23 women) were interviewed.

Table 1: Summary of the sample size for the study

$\begin{array}{lll}\text { Districts } & \text { Villages } & \text { Participants } \\ \text { Kasungu } & \text { Simndemba } & 94 \\ & \text { Kalolo } & 95 \\ \text { Dedza } & \text { Kapenuka } & 94 \\ & \text { Chinkombero } & 92 \\ \text { Total } & & \mathbf{3 7 5}\end{array}$

Data were analysed using the thematic analysis (Jugder, 2016) where the data generated in form of statements from respondents, notes and observations from the researcher and assistants were recorded verbatim from interviews and focus group discussions. Transcripts were made for all the recordings. These were imported into the NVivo9, a software that is being used for managing, coding and exploring qualitative data. Themes were drawn from NVivo 9 extracts and the data generated were further explored for contextual meanings. Descriptive statistics such as frequencies, percentages and mean were computed for data produced from responses made by research participants in the survey that was done as part of the study. Overall, the data were explored by analysing the contents and deductions were inferred from reports generated.

\section{Results and Discussion}

\section{Perceptions of Power}

Three themes emerged from the processed data from this study. The study shows that power is generally perceived firstly as; capacity to influence and secure compliance, 
Creative Commons User License: CC BY-NC-ND

Abstracted by: EBSCOhost, Electronic Journals Service (EJS),

Google Scholar, Journal Seek, Scientific Commons,

Food and Agricultural Organization (FAO), CABI and Scopus
Journal of Agricultural Extension

Vol. 23 (3) July, 2019

ISSN(e): 24086851; ISSN(Print); 1119944X

http://journal.aesonnigeria.org

http://www.ajol.info/index.php/iae

Email: editorinchief@aesonnigeria.org

secondly as ability to lead actions and decision making and finally as potential to influence people's way of thinking. The data as presented in Table 2 show that research participants from different study locations implementing different development interventions shared similar perceptions of power. Results presented in the Table 2 illustrate that most of the ordinary research participants who were benefitting from both development interventions shared all the three perceptions of power presented in the Table 2, while, few powerful social actors perceived 'potential ability to influence way of thinking and doing things' as power. The findings suggest that there were common factors among research participants that informed the shared understanding of the concept of power in the study locations. The data intimates that perceived degrees of power and the act of belonging to the same social setting may have affected the shared interpretations of social power. The results also suggest that factors unique to categories of research participants motivated specific constructs of the concept of power. Finding from the current study supports observations made in literature that some people share similar understanding of power, while they differ on other interpretations of the concept (Mann, 2012). The different perceptions of power by respondents with different degrees of power from all study locations are described in subsequent subsections.

\section{Social Power as Capacity to Influence Decisions and Secure Compliance}

Table 2 shows that most (>98\%) of the respondents stated that power to them meant the 'capacity of a social actor to influence decisions and secure compliance' of other social actors. They explained that social power is the capability of a social actor to enable fellow social actors to follow instructions, way of thinking, and way of doing things to achieve specific objectives. These were dominant responses among powerful participants especially village leaders. A review of the responses showed that village leaders expected ordinary men and women to comply with instructions they give them at all times. The powerful social actors explained that compliance was an important aspect of their culture. This result resonates with (Ahmed and Shafiq, (2014) submission that power is the ability of an actor to control decisions and actions of other social actors with a view to reaching specific outcomes.

On the other hand, ordinary social actors gave several propositions showing that 'compliance' connotes social power (Table 2). These findings support observations made by other scholars who reported that power aims to secure compliance (Tost, 2015) and compliance is therefore an indicator of the influence of social power. Ordinary research participants stated that they complied with orders and instructions from mainly village leaders because of loyalty of the ordinary research participants given that they are citizens in the villages. They justified that they complied because of the respect they have for their leaders although the ordinary research participants may have reservations for some orders and instructions. They also explained that they complied out of fear of reprisals from those in authority. Participants further explained that non-compliance in respective villages attracted penalties. Penalties are imposed subjectively by the traditional village leaders. The reasons given for compliance also explained how social actors especially leaders appropriated power in the study locations. The powerful research participants explained that they secure compliance among their subjects because the leaders have authority in their 
Creative Commons User License: CC BY-NC-ND

Abstracted by: EBSCOhost, Electronic Journals Service (EJS),

Google Scholar, Journal Seek, Scientific Commons,

Food and Agricultural Organization (FAO), CABI and Scopus
Journal of Agricultural Extension

Vol. 23 (3) July, 2019

ISSN(e): 24086851; ISSN(Print); 1119944X

http://journal.aesonnigeria.org

http://www.ajol.info/index.php/iae

Email: editorinchief@aesonnigeria.org

areas of jurisdiction. They made these narrations based on their experiences in the study locations. One of the accounts was as follows:

Power is the authority to persuade ordinary people to carry out activities concerning family planning and safe motherhood such as sharing messages of family planning with each other and encouraging fellow women to attend antenatal clinics before child birth as well as convincing them to attend under-five clinics. It is also ability of the people at village level to undertake collective actions in influencing leaders in this village to ask our government to improve provision of health services such as underfive clinics for their own good.

Narrations of the research participants suggest that power was ascertained from capabilities of a social actor to enable others make decisions or take action and subsequent outcome of the efforts. The intermediate outcome of persuasive efforts is referred to as compliance in this study. Responses of the research participants revealed that those who belonged to the category of powerful research participants view influence and compliance as aims of using social power in social interactions. One of the accounts from research participants was as follows:

\section{'I understand power as the ability to secure compliance among social actors'}

On the other hand, the ordinary research participants viewed influence and compliance simply as responses to requests that they made to the powerful social actors. This indicates that the powerful social actors aim to influence other social actors. This is because they were expressing the ideas from their experiences. The concept of compliance explains premises for the reactions by ordinary men and women to orders and instructions from village heads and elected leaders. The basic argument of the research participants in the villages was that they complied with orders from village heads for cultural reasons, which are respect and loyalty to those in authority. Additionally, leaders complied with requests from subordinates because they had obligations to help them. For instance, village heads are obliged to give responses to requests made by the ordinary people in their areas of jurisdiction. The concept of compliance as a construct of social power in this study is linked to respect for culture. It was important to understand culture in this context for one to be able to follow the social power dynamics in both food security and reproductive health interventions. The findings in regard to compliance supports results of other studies that reported that different sources or forms of power influence compliance of social actors in inferior positions regardless of whether the power is actually used or not, as the social actors may act based on implied or imagined power (Mittal and Elias, 2016; Cenkci, 2018).

\section{Social Power as Ability to Lead Decision-Making and Actions}

Ability to lead decision-making and actions was another perception of power established by the study. This is supported by data presented in Table 2 as an excerpt of one of the key informant interviews. Some of the results in Table 2 demonstrate that most $(>98 \%)$ of the study respondents (including the powerful and ordinary social actors) perceived 'power' as the leadership ability of a social actor, while few participants with high degree of power share the construct. The results suggest that both powerful actors and ordinary participants 
Creative Commons User License: CC BY-NC-ND

Abstracted by: EBSCOhost, Electronic Journals Service (EJS),

Google Scholar, Journal Seek, Scientific Commons,

Food and Agricultural Organization (FAO), CABI and Scopus
Journal of Agricultural Extension

Vol. 23 (3) July, 2019

ISSN(e): 24086851; ISSN(Print); 1119944X

http://journal.aesonnigeria.org

http://www.ajol.info/index.php/iae

Email: editorinchief@aesonnigeria.org

consider the ability to lead others as connoting power. Further analysis of responses of the study participants describing social power showed that they conceived it as ability and the act of guiding fellow social actors to plan and implement activities and programmes serving common interests of the participants in the study areas.

Achieving food security and safe motherhood were common interests of research participants examined in this study. It was therefore not surprising to find that authority of a social actor informs the ability of a social actor to lead others. Authority is appropriated through nomination or election, by the people, and designation by the government in both interventions, but separate study locations. Possession of technical knowledge of food security and reproductive health interventions gave some social actors the mandate to lead in decision-making, and sharing of information and knowledge on the interventions hence such people are seen as powerful. This was true with agriculture extension workers, health surveillance assistants, lead farmers and reproductive health task forces in respective study locations. On the other hand, culture of the people mandated other social actors to take lead at village level. In both cases, leadership positions gave social actors powerful status in the study area as one of the research participants observed:

'Social power to me means guiding others, especially ordinary people, who are without positions in planning for meetings of crop production activities and even marketing'

This view was common to all research participants. The ability to lead other social actors is shown through different processes and activities. The research participants also explained that leadership ability is shown when some social actors such as lead farmers and extension workers demonstrate ways of planting crops, applying fertilizers to crops, preserving sweet potatoes, and processing sweet potatoes for consumption. This construct suggests that research participants determined the meaning of power from accomplishments of certain social actors in the specific contexts.

\section{Social Power as Potential Ability to Influence Ways of Thinking and Acting}

The study also revealed that social power is understood as potential ability to influence way of thinking and performing activities of interest to a group of social actors in the research sites and development interventions. Typical views of study respondent when addressing questions that sought to understand their interpretations of social power indicate

Development workers naturally affect the way we do things here; for instance, sometimes we do what other extension workers used to advice upon seeing any new extension worker because we feel they represent some power with their expertise

Similar views were expressed by respondents with different degrees of power, but mainly the less powerful as summarised in Table 2 . Table 2 shows that half $(>50 \%)$ of the respondents perceived power as potential ability to influence. However, the data in Table 2 shows that relatively few powerful social actors from both agriculture extension workers $(3.7 \%)$ and sexual and reproductive health interventions $(1.3 \%)$ and study locations shared this perception of power compared to the other two perceptions discussed in the previous subsections. The results suggest that factors perceived to inform social power qualify some social actors as influential. Experts, local leaders such as village headpersons, lead 
Creative Commons User License: CC BY-NC-ND

Abstracted by: EBSCOhost, Electronic Journals Service (EJS),

Google Scholar, Journal Seek, Scientific Commons,

Food and Agricultural Organization (FAO), CABI and Scopus
Journal of Agricultural Extension

Vol. 23 (3) July, 2019

ISSN(e): 24086851; ISSN(Print); 1119944X

http://journal.aesonnigeria.org

http://www.ajol.info/index.php/iae

Email: editorinchief@aesonnigeria.org

farmers, agriculture extension workers, sexual and reproductive health task force members are some of the social actors in the study areas that have potential to influence fellow social actors' way of thinking and doing things in both interventions of focus. This further insinuates that social power can be derived from some social elements. The findings also suggest that most of the powerful social actors hold other views of power than the ones discussed in the study.

\section{Implications on Power Theory and Practice}

Findings of the current study have implications on theories of power, power-related policies and practices. They enrich theories of power, which have explained the concept of power based on behaviour of social actors. The results also inform empowerment strategies that are dependent on the theories of power in development.

Similarly, the findings are important to implementers of development interventions. They can be useful to them for planning empowerment interventions. The implementers can use the perceptions established by the current study to widen the scope of power. This can make empowerment strategies more encompassing. They can also be used to come up with practical empowerment outcomes.

The results can also be useful to both policy makers and policy implementers in the study locations in several ways. Policy makers in the study districts can use the findings to enrich and reorient policies and strategies of empowerment to address shortcomings of the current policies and strategies that are limited in focus.

Table 2: Social power perceptions by research participants

\begin{tabular}{lllll}
\hline $\begin{array}{l}\text { Social power } \\
\text { perceptions }\end{array}$ & \multicolumn{2}{l}{$\begin{array}{l}\text { Agriculture extension } \\
\text { workers Site Participants }\end{array}$} & $\begin{array}{l}\text { Health workers Sites } \\
\text { participants }\end{array}$ \\
& ordinary & powerful & ordinary & powerful social \\
& social actors & social & social actors & actors \\
& actors & &
\end{tabular}

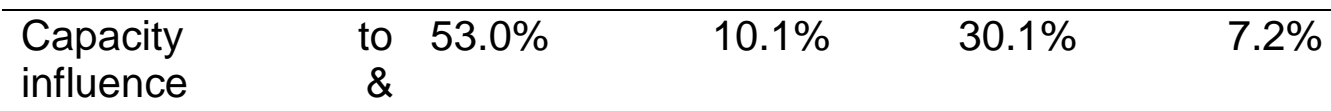

securing

Compliance

$\begin{array}{lllll}\text { Leadership ability } & 55.2 \% & 6.1 \% & 30.1 \% & 8.5 \%\end{array}$

for

decision-making

and

actions

$\begin{array}{lllll}\text { Potential ability to } & 30.0 \% & 3.7 \% & 23.7 \% & 1.3 \%\end{array}$ Influence

Source: Field Survey, 2013 
Creative Commons User License: CC BY-NC-ND

Abstracted by: EBSCOhost, Electronic Journals Service (EJS),

Google Scholar, Journal Seek, Scientific Commons,

Food and Agricultural Organization (FAO), CABI and Scopus
Journal of Agricultural Extension

Vol. 23 (3) July, 2019

ISSN(e): 24086851; ISSN(Print); 1119944X

http://journal.aesonnigeria.org

http://www.ajol.info/index.php/iae

Email: editorinchief@aesonnigeria.org

\section{Conclusion and Recommendation}

Power means compliance, ability to lead subordinates and capacity to influence people's decisions. Power describe from experiences of social actors is perceived as powerful and those viewed as powerless in power-play. This is a departure from the conventional ways of examining social power, which normally focuses on behaviour of social actors and outcomes of efforts by the actors. The study extends the thinking around the study of power by suggesting that it should also focus on experiences of protagonists and those perceived as objects in power-play. Stakeholders of development intervention in rural areas should consider experienced social actors as powerful. This will enhance effective extension policy process aimed at agriculture and health development intervention among rural populace.

\section{References}

Ahmed, M. \& Shafiq, S. (2014). The Impact of organizational culture on organizational performance: A case study of telecom sector. Global Journal of Management and Business Research (A), 14(3), 21-30.

Cenkci, A. T. (2018). Leader Power, Conflict Handling Styles, and Subordinate Compliance: A Study on Information Technology Professionals in Turkey. International Journal of Management and Economics, 54(1), 18-35.

Dowding, K. (2012). Why should we care about the definition of power? Journal of Political Power, 5:119-135.

Jugder, N. (2016). The Thematic Analysis of Interview Data: An Approach used to examine the Influence of the Market on Curricular Provision in Mongolian Higher Education Institutions. Hillary Place Papers, 3rd edition, University of Leeds.

Mann, M. (2012). The Sources of Social Power: Volume 3, Global Empires and Revolution, 1890-1945, Cambridge University Press.

Mittal, R., \& Elias, S. M. (2016). Social power and leadership in cross-cultural context. Journal of Management Development, 35(1), 58-74.

Pansardi, P. (2012). Power to and power Over: Two distinct concepts of power? Journal of Political Power, 5, 73-89.

Pereira, G., Prada, R., \& Pedro, A. (2016). Integrating social power into the decisionmaking

of cognitive agents. Artificial Intelligence, 241, 1-44.

Tost, L.P. (2015). When, Why, and How Does Power Holders "Feel the Power"? Examining the Links between Structural and Psychological Power and Reviving the Connection between Power and Responsibility. Journal of Research in Organizational Behaviour, 35(1), 29-56. 